\title{
Determination of Mould and Aflatoxin Contamination in Tarhana, a Turkish Fermented Food
}

\author{
Hilal Colak, ${ }^{1}$ Hamparsun Hampikyan, ${ }^{2}$ Enver Baris Bingol, ${ }^{1}$ Omer Cetin, ${ }^{1}$ \\ Meryem Akhan, ${ }^{3}$ and Sumeyre Ipek Turgay ${ }^{3}$ \\ ${ }^{1}$ Department of Food Hygiene and Technology, Faculty of Veterinary Medicine, Istanbul University, Avcilar, 34320 Istanbul, Turkey \\ ${ }^{2}$ The School of Vocational Studies, Beykent University, Buyukcekmece, 34500 Istanbul, Turkey \\ ${ }^{3}$ Academic Hygiene KGaA, Training, Audit and Consulting Services, Kuştepe Mahallesi, Tomurcuk Sokak, İzmen Sitesi, Sisli, \\ 34387 Istanbul, Turkey \\ Correspondence should be addressed to Hilal Colak, hcolak@istanbul.edu.tr
}

Received 28 October 2011; Accepted 20 December 2011

Academic Editors: K. Ohmiya, G. K. Paterson, and J. Qiu

Copyright () 2012 Hilal Colak et al. This is an open access article distributed under the Creative Commons Attribution License, which permits unrestricted use, distribution, and reproduction in any medium, provided the original work is properly cited.

Tarhana is a popular traditional Turkish cereal-based fermented food product mainly produced at home or at home-scale level. Some certain mould species can grow even at low moisture and $\mathrm{pH}$ values and produce aflatoxins in food. This study was conducted to determine aflatoksin levels in tarhana. For this purpose, a total of 138 tarhana powder samples were collected from bazaars in Istanbul and analyzed for aflatoxins, mould contamination, and some physco-chemical parameters. As a result, 32 out of 138 tarhana samples $(23.2 \%)$ were found to be contaminated with aflatoxins in the range of $0.7-16.8 \mu \mathrm{g} / \mathrm{kg}$, whereas 29 samples contained Aflatoxin B1 (AFB1) ranging from $0.2-13.2 \mu \mathrm{g} / \mathrm{kg}$. All samples (100\%) contaminated with moulds in the range of $1.4 \times 10^{1}-5.8 \times 10^{7} \mathrm{cfu} / \mathrm{g}$. The average $\mathrm{pH}$, moisture and $\mathrm{a}_{w}$ results were detected as $3.82,12.71 \%$, and 0.695 , respectively.

\section{Introduction}

Fermented cereal-yoghurt mixtures play an important role in the diets of many people in the Middle East, Asia, Africa, and some parts of Europe [1-3]. Safety and some nutritional benefits such as improvement of protein digestibility, degradation of antinutritional factors have been attributed to fermented foods, and therefore they have promoted for safety and nutritional purpose [4]. Tarhana is a popular traditional Turkish cereal-based fermented food product mainly produced at home or at home-scale level $[5,6]$. Tarhana is prepared by mixing wheat flour, yoghurt, yeast, salt, some raw or cooked vegetables (tomato, pepper, and onion), and spices (mint, basil, dill, paprika, tarhana herb, etc.) followed by lactic and alcoholic fermentation for one to seven days. The dough at fermentation is called as wet tarhana. After fermentation, the mixture is dried in the sun as a lump, nugget, or thin layers to obtain dry tarhana. Finally, it is ground to powders smaller than $1 \mathrm{~mm}[1,4,5,7]$. Since there is no standard procedure in the production method of tarhana, its nutritional properties depend heavily on the ingredients and the amount used in the recipe $[4,8]$.
Methods for production of tarhana may vary from one place to another, but cereals and yoghurt are always the major component $[2,3,9,10]$. Production process of traditional tarhana is shown in Figure 1.

Tarhana is mainly used in the form of a thick and creamy soup reconstituting with water followed by simmering and is consumed at lunch or dinner especially on cold days in Turkey $[9,11]$. It is also locally consumed as a snack after it has been dried as thin layer or nugget, not to be ground [8]. There are four different types of tarhana, stated by Turkish Standardization Institute: flour tarhana, göce (cracked wheat) tarhana, semolina tarhana, and mixed tarhana. The difference between them is the usage of the wheat flour, cracked wheat, and semolina separately or as combinations in the recipe [5].

Tarhana-like products are known under different names in the other countries: kishk (sour milk-wheat mixture with boiled chicken stock) in Egypt, Syria, Lebanon, and Jordan, kushuk (milk-sour dough mixture with turnips) in Iraq, and tahonya/talkuna (fermented cereal mixture with vegetables) in Hungary and Finland $[1,2,5,10,12]$. 


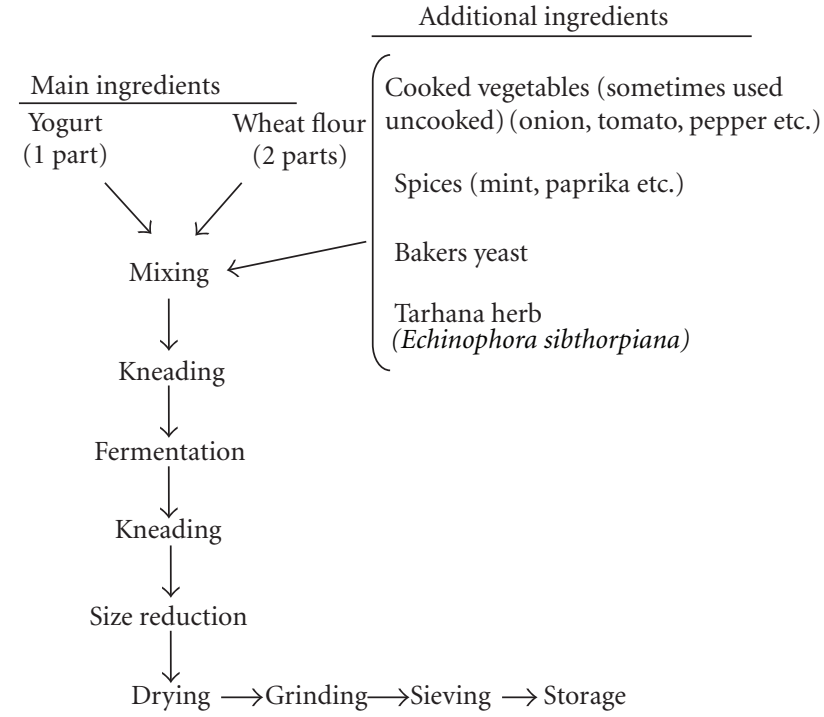

FIGURE 1: Flow diagram for traditional tarhana production [12].

Lactic acid bacteria and yeast are responsible for acid formation during fermentation in Tarhana [1]. The low $\mathrm{pH}(3.8-4.5)$ and low moisture content (about 10\%) of tarhana provide a bacteriostatic effect against pathogenic and spoilage microorganisms $[1,2,12]$. However, some certain mould species such as Aspergillus, Penicillium, and Fusarium can grow even at low moisture and $\mathrm{pH}$ values and produce mycotoxins in several food commodities $[13,14]$.

Among all mycotoxins, aflatoxins are a group of highly toxic secondary metabolic products named as aflatoxin $\mathrm{B} 1$ (AFB1), aflatoxin B2 (AFB2), aflatoxin G1 (AFG1), and aflatoxin G2 (AFG2) $[15,16]$. Aflatoxins are carcinogenic, mutagenic, teratogenic, and immunosuppressive to most animal species and humans [17]. AFB1 has the highest potency as a toxin and is classified as group I carcinogen by International Agency for Research on Cancer (IARC) [18]. The order of toxicity, AFB1 > AFG1 > AFB2 > AFG2, indicates that the terminal furan moiety of AFB1 is the critical point for determining the degree of biological activity of this group of mycotoxins [19]. Aflatoxins easily occur in feeds and foods during growth, harvest, or storage [20].

Due to their frequent occurrence and toxicity, guidelines and tolerance levels of aflatoxins have been set in several countries including Turkey. According to the Turkish Food Codex, the maximum residue limits for AFB1 and total aflatoxin in risky foods is 5 and $10 \mu \mathrm{g} / \mathrm{kg}$, respectively [21].

Although several studies are available for aflatoxin levels in different food types which are consumed in Turkey, there is very little information on the presence of aflatoxins in tarhana. On the other hand, limited studies were conducted on mould contamination of tarhana. Therefore, this study was planned to determine aflatoxin levels and mould contamination in tarhana powder which are consumed to a great extend at Turkish kitchen and to compare the obtained results with maximum aflatoxin tolerance limits accepted by the Turkish Food Codex.
TABLE 1: Number of samples collected according to month.

\begin{tabular}{lllc}
\hline Season & Month & Year & $\begin{array}{c}\text { Number of } \\
\text { sample }\end{array}$ \\
\hline Autumn & $\begin{array}{l}\text { September-October- } \\
\text { November }\end{array}$ & 2010 & 42 \\
Winter & $\begin{array}{l}\text { December-January- } \\
\text { February }\end{array}$ & $2010-2011$ & 56 \\
Spring & March-April-May & 2011 & 40 \\
\hline
\end{tabular}

\section{Materials and Methods}

2.1. Samples. During the period September-May 2011, a total of 138 tarhana powder samples were collected randomly from bazaars located in different regions of Istanbul (Figure 2). Samples were transported under cold conditions from their place of collection to the laboratory. The number of samples gathered according to month bought was given in Table 1.

\subsection{Aflatoxin Analysis}

2.2.1. Sample Preparation. Sample preparation procedures were performed according to the instructions of the test kit (Rida Aflatoxin Column Art no.: R5001/5002, R-Biopharm, Darmstadt, Germany) manual [22]. $25 \mathrm{~mL}$ of methanol (70\%) was added to $5 \mathrm{~g}$ of tarhana. Afterwards, the solution was extracted by mixing gently for 10 minutes at room temperature. The extract was filtered through a paper filter and $15 \mathrm{~mL}$ of distilled water were added to $5 \mathrm{~mL}$ of filtered solution. $0.25 \mathrm{~mL}$ Tween 20 were added and stirred for 2 minutes, followed by entire amount of the sample solution $(20 \mathrm{~mL})$ passing over the column. Clean up procedure was performed according to the kit's manual. Toxin containing eluate was diluted 1:10 with the sample dilution buffer (supplied with the test kit) and used $50 \mu \mathrm{L}$ per well in the assay.

2.2.2. Test Procedure of Total Aflatoxins. According to Ridascreen Aflatoxin Total (Art no.: 4701) test kit manual [23], $50 \mu \mathrm{L}$ of the standard solutions or prepared sample in duplicate were added to the wells of microtiter plate. Then $50 \mu \mathrm{L}$ of the diluted enzyme conjugate and $50 \mu \mathrm{L}$ of the diluted antibody solution were added to each well. The solution was mixed gently, and incubated for $30 \mathrm{~min}$ at room temperature $\left(20-25^{\circ} \mathrm{C}\right)$ in the dark. The unbound conjugate was removed during washing for three times (ELISA Washer ELX 50, Bio-tek Inst.). Afterwards, $100 \mu \mathrm{L}$ of substrate/chromogen solution was added to each well, mixed gently, and incubated for $30 \mathrm{~min}$ at room temperature (20$25^{\circ} \mathrm{C}$ ) in the dark. Then, $100 \mu \mathrm{L}$ of the stop solution ( $1 \mathrm{M}$ $\mathrm{H}_{2} \mathrm{SO}_{4}$ ) was added to each well and the absorbance was measured at $450 \mathrm{~nm}$ in ELISA plate reader (ELX 800, Bio-tek Inst.). The mean lower detection limit is $0.25 \mu \mathrm{g} / \mathrm{kg}$.

2.2.3. Test Procedure of AFB1. According to Ridascreen Aflatoxin B1 30/15 (Art no.: 1211) test kit manual [24], $50 \mu \mathrm{L}$ of the standard solutions or prepared sample in duplicate 


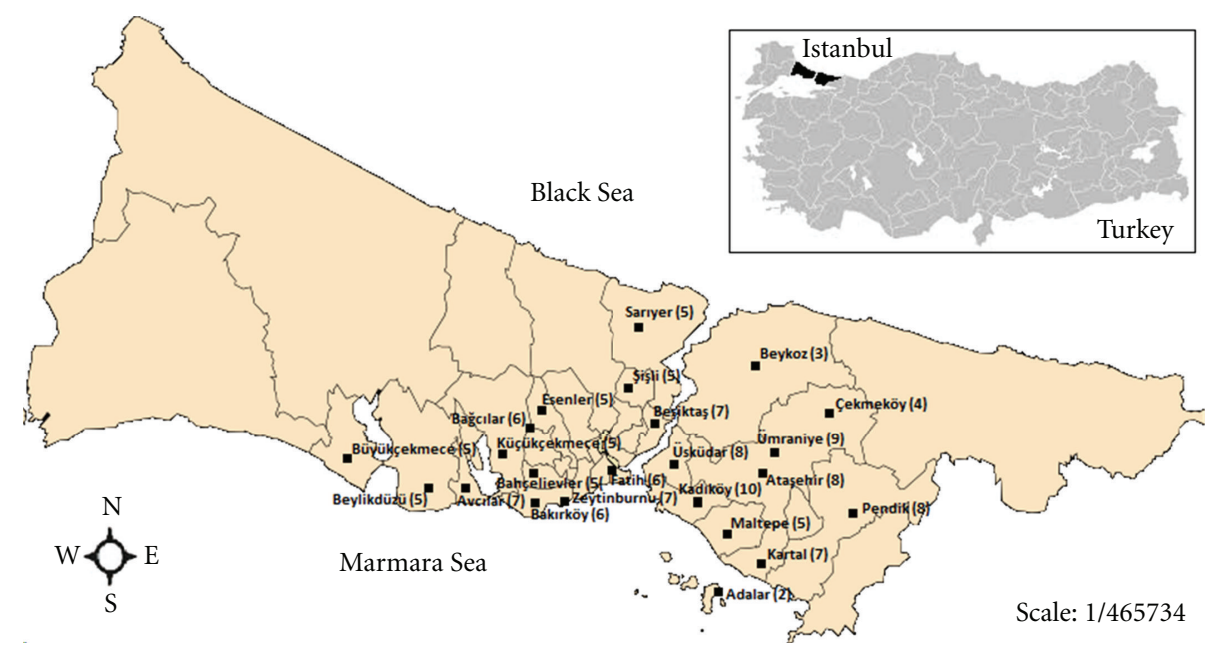

Figure 2: Map of samples collected in Istanbul, Turkey.

was added to the wells of microtiter plate. Then $50 \mu \mathrm{L}$ of the enzyme conjugate and $50 \mu \mathrm{L}$ of the anti-aflatoxin antibody solution were added to each well, mixed gently and incubated for $30 \mathrm{~min}$ at room temperature $\left(20-25^{\circ} \mathrm{C}\right)$. The washing procedure was applied for three times (ELISA Washer ELX 50, Bio-tek Inst.). After the washing step, $100 \mu \mathrm{L}$ of substrate/chromogen solution were added to each well and mixed gently and incubated for $30 \mathrm{~min}$ at room temperature $\left(20-25^{\circ} \mathrm{C}\right)$ in the dark. Finally, $100 \mu \mathrm{L}$ of the stop solution $\left(1 \mathrm{M} \mathrm{H}_{2} \mathrm{SO}_{4}\right.$ ) were added to each well and the absorbance was measured at $450 \mathrm{~nm}$ in ELISA plate reader (ELX 800, Bio-tek Inst.). The mean lower detection limit is $1.0 \mu \mathrm{g} / \mathrm{kg}$.

2.2.4. Determination of Moisture and Water Activity. Moisture contents of tarhana samples were determined by drying a homogeneous mixture of the sample in an oven (Heraeus, Germany) at $105 \pm 2^{\circ} \mathrm{C}$ until a constant weight was obtained according to AOAC procedures [25]. The water activity analysis was determined by means of water activity meter (Decagon, AquaLab Lite, USA).

2.2.5. Determination of $p H$. The $\mathrm{pH}$ was determined after mixing a $10 \mathrm{~g}$ sample with $90 \mathrm{~mL}$ distilled water $(1 / 10$ sample/water) and the $\mathrm{pH}$ value measurements were carried out using a Hanna pH meter (Hanna HI-9321, Woonsocket, Rhode Island, USA), equipped with a FC220B electrode (Hanna HI-9321, Woonsocket, Rhode Island, USA), after calibration with standard buffers of $\mathrm{pH} 4.0$ and 7.0 [26].

2.2.6. Mould Analysis. Mould was defined on Dichloran Rose Bengal Chloramphenicol agar with Chloramphenicol Selective supplement (DRBC, Oxoid, CM0727, and SR0078). Spread plates were incubated at $25^{\circ} \mathrm{C}$ for 5 days [27].

\section{Results and Discussion}

The distribution and evaluation of mould counts, aflatoxin amounts, $\mathrm{pH}$, moisture, and water activity values of analyzed tarhana samples are given in Tables 2, 3, and 4, respectively.

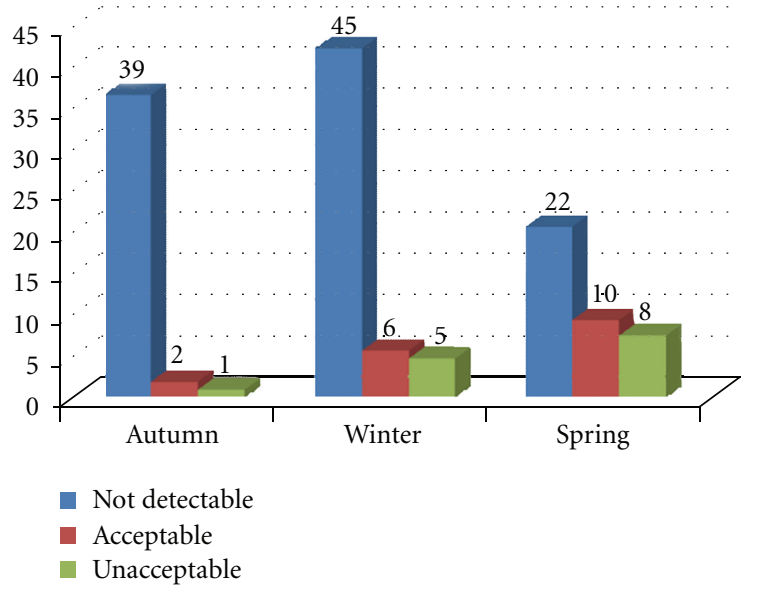

Figure 3: The number of acceptable and unacceptable samples according to Turkish Food Codex (TFC).

In this study 32 ( 3 in autumn, 11 in winter, 18 in spring) out of 138 tarhana samples (23.2\%) were found to be contaminated with aflatoxins in the range of $0.7-16.8 \mu \mathrm{g} / \mathrm{kg}$, whereas 29 out of $138(21.0 \%)$ tarhana samples contained AFB1 ranging from $0.2-13.2 \mu \mathrm{g} / \mathrm{kg}$ (Table 3). According to these results, 14 tarhana samples exceeded the maximum limits of AFB1 $(5 \mu \mathrm{g} / \mathrm{kg})$ and total aflatoxin $(10 \mu \mathrm{g} / \mathrm{kg})$ set in the Turkish Food Codex [21] (Figure 3).

Because the presence of aflatoxins in food is a hazard to human health, numerous studies have been conducted in different countries and also in Turkey to examine the presence and levels of aflatoxins in various food commodities. However, there is very little information on the presence of aflatoxins in tarhana, except for a report by Arici [28], who detected AFB1 in 4 out of 31 (12.9\%) tarhana samples. Our results were higher than the results of the above-mentioned researcher.

The mould contamination rate on examined tarhana samples was fairly high. As can be seen from Table 2, all 
TABLE 2: Distribution and evaluation of mould contamination in Tarhana samples $(n=138)$.

\begin{tabular}{lcccccccc}
\hline Range (cfu/g) & $\mathrm{ND}^{*}(<10)$ & 10 to $<10^{2}$ & $10^{2}$ to $<10^{3}$ & $10^{3}$ to $<10^{4}$ & $10^{4}$ to $<10^{5}$ & $10^{5}$ to $<10^{6}$ & $10^{6}$ to $<10^{7}$ & $>10^{7}$ \\
\hline Number & - & 13 & 22 & 43 & 32 & 15 & 8 \\
Percentage (\%) & - & 9.4 & 15.9 & 31.2 & 23.2 & 10.9 & 5.8 & 3.6 \\
\hline
\end{tabular}

TABLE 3: Mould counts and Aflatoxin amounts of contaminated tarhana samples.

\begin{tabular}{|c|c|c|c|c|}
\hline Season & Sample no. & $\begin{array}{l}\text { Mould Count } \\
\quad(\mathrm{cfu} / \mathrm{g})\end{array}$ & $\begin{array}{c}\text { Total } \\
\text { aflatoxins } \pm \mathrm{SE} \\
(\mu \mathrm{g} / \mathrm{kg})\end{array}$ & $\begin{array}{c}\mathrm{AFB} 1 \pm \mathrm{SE} \\
(\mu \mathrm{g} / \mathrm{kg})\end{array}$ \\
\hline \multirow{3}{*}{ Autmn } & No: 4 & $3.8 \times 10^{5}$ & $4.1 \pm 0.1$ & $2.9 \pm 0.3$ \\
\hline & No: 7 & $1.3 \times 10^{6}$ & $10.5 \pm 0.2$ & $9.7 \pm 0.6$ \\
\hline & No: 11 & $4.1 \times 10^{5}$ & $1.2 \pm 0.1$ & $0.7 \pm 0.4$ \\
\hline \multirow{11}{*}{ Winter } & No: 18 & $2.1 \times 10^{4}$ & $3.6 \pm 0.7$ & ND \\
\hline & No: 25 & $3.5 \times 10^{6}$ & $15.1 \pm 0.8$ & $8.8 \pm 0.9$ \\
\hline & No: 32 & $5.7 \times 10^{6}$ & $16.2 \pm 0.9$ & $10.4 \pm 0.4$ \\
\hline & No: 45 & $5.8 \times 10^{7}$ & $16.8 \pm 0.5$ & $13.2 \pm 0.3$ \\
\hline & No: 48 & $1.9 \times 10^{5}$ & $8.2 \pm 0.6$ & $4.4 \pm 0.2$ \\
\hline & No: 53 & $1.2 \times 10^{5}$ & $6.2 \pm 0.9$ & $3.4 \pm 0.2$ \\
\hline & No: 57 & $6.9 \times 10^{5}$ & $11.9 \pm 0.3$ & $10.2 \pm 0.7$ \\
\hline & No: 59 & $4.3 \times 10^{4}$ & $3.4 \pm 0.1$ & ND \\
\hline & No: 63 & $1.2 \times 10^{7}$ & $14.1 \pm 0.2$ & $10.4 \pm 0.7$ \\
\hline & No: 68 & $4.1 \times 10^{5}$ & $2.6 \pm 1.1$ & $2.1 \pm 0.3$ \\
\hline & No: 71 & $4.8 \times 10^{6}$ & $12.1 \pm 0.3$ & $7.5 \pm 0.4$ \\
\hline \multirow{18}{*}{ Spring } & No: 74 & $5.2 \times 10^{4}$ & $7.6 \pm 0.5$ & $4.8 \pm 0.8$ \\
\hline & No: 76 & $3.5 \times 10^{4}$ & $3.1 \pm 0.7$ & $2.6 \pm 0.4$ \\
\hline & No: 80 & $2.2 \times 10^{6}$ & $11.6 \pm 0.9$ & $6.8 \pm 0.7$ \\
\hline & No: 82 & $2.8 \times 10^{5}$ & $1.7 \pm 0.2$ & $0.8 \pm 0.3$ \\
\hline & No: 87 & $6.1 \times 10^{3}$ & $0.9 \pm 0.1$ & $0.5 \pm 0.1$ \\
\hline & No: 95 & $1.1 \times 10^{7}$ & $10.8 \pm 1.2$ & $8.7 \pm 0.4$ \\
\hline & No: 99 & $4.5 \times 10^{3}$ & $2.7 \pm 0.3$ & $1.8 \pm 0.2$ \\
\hline & No: 101 & $1.7 \times 10^{6}$ & $14.3 \pm 1.1$ & $7.8 \pm 0.9$ \\
\hline & No: 107 & $5.8 \times 10^{5}$ & $11.1 \pm 0.9$ & $8.3 \pm 0.6$ \\
\hline & No: 108 & $2.4 \times 10^{7}$ & $12.5 \pm 0.5$ & $9.1 \pm 0.3$ \\
\hline & No: 111 & $1.8 \times 10^{4}$ & $0.7 \pm 0.2$ & $0.2 \pm 0.1$ \\
\hline & No: 113 & $6.2 \times 10^{6}$ & $12.3 \pm 0.8$ & $10.6 \pm 0.4$ \\
\hline & No: 115 & $6.4 \times 10^{5}$ & $5.2 \pm 0.5$ & $3.1 \pm 0.2$ \\
\hline & No: 119 & $3.2 \times 10^{7}$ & $15.1 \pm 0.8$ & $8.6 \pm 0.5$ \\
\hline & No: 120 & $1.8 \times 10^{3}$ & $2.9 \pm 0.3$ & $1.1 \pm 0.2$ \\
\hline & No: 125 & $7.2 \times 10^{5}$ & $4.5 \pm 0.6$ & $1.4 \pm 0.5$ \\
\hline & No: 127 & $3.2 \times 10^{4}$ & $6.2 \pm 0.2$ & $3.8 \pm 0.7$ \\
\hline & No: 134 & $3.1 \times 10^{3}$ & $0.8 \pm 0.3$ & ND \\
\hline
\end{tabular}

ND: not detected, SE: standart error.

samples $(100 \%)$ contaminated with moulds in the range of $1.4 \times 10^{1}-5.8 \times 10^{7} \mathrm{cfu} / \mathrm{g}$. The average count was detected as $4.6 \times 10^{3} \mathrm{cfu} / \mathrm{g}$.

In Turkey, there are few studies on mould contamination in tarhana. In a study conducted by Soyyigit [29], the yeastmould counts were detected as $<10-3.3 \times 10^{7} \mathrm{cfu} / \mathrm{g}$ in 27 examined tarhana samples produced in Isparta city. Coskun [30] reported the mean yeast-mould counts in tarhana samples as $3.04 \times 10^{3}, 3.52 \times 10^{3}$, and $3.37 \times 10^{1} \mathrm{cfu} / \mathrm{g}$ in Edirne, Kırklareli and Tekirdağ cities, respectively. Daglioglu et al. [31] found the mould/yeast contamination at a level of $1.5 \times 10^{3} \mathrm{cfu} / \mathrm{g}$ in traditional dried tarhana samples. 
TABLE 4: pH, moisture, and water activity results of analyzed tarhana samples.

\begin{tabular}{lccc}
\hline Parameters & Minimum & Maximum & Average \\
\hline $\mathrm{pH}$ & 3.25 & 4.50 & 3.82 \\
Moisture (\%) & 10.35 & 17.85 & 12.71 \\
(Dry matter \%) & $(89.65)$ & $(82.15)$ & $(87.29)$ \\
Water activity $\left(a_{w}\right)$ & 0.658 & 0.895 & 0.695 \\
\hline
\end{tabular}

As expected, samples with high mould contamination contained high aflatoxin levels (Table 3). Source of mould and aflatoxin contamination in tarhana may result from wheat flour and spices used in the production. Wheat flour is an ingredient used in many foods in European and American culture and also is main ingredient of tarhana. Flour is generally regarded as a microbiologically safe product as it is a low water activity commodity [32]. However, toxigenic moulds may contaminate and grow in flour at different phases of production and processing, mainly in appropriate humidity and temperature conditions. Hence, there are several researches on mould contamination and aflatoxin levels in wheat and wheat flour [32-34]. Spices are exposed to a wide range of microbial contamination due to poor collection conditions, unpretentious production process, and extended drying times. In addition, spices can be contaminated through dust, waste water, and animal/human excreta in unpackaged spices which are sold in markets and bazaars. Several studies have demonstrated that spices are contaminated with various microorganisms including toxigenic moulds (especially Aspergillus spp.) and aflatoxins [35]. Therefore, spices pose health problems because they are often added to foods without further processing or are eaten raw. Therefore, to protect the consumer's health, it should not be used mould and aflatoxin-contaminated flour and spices in tarhana production.

As can be seen from Table 4 the average $\mathrm{pH}$, moisture, and $a_{w}$ results were $3.82,12.71 \%$, and 0.695 , respectively. Similar results were also reported by other researchers $[3,9$, $36,37]$. It is obvious that moisture has a great importance for the safe storage of food regarding microorganisms, particularly certain species of moulds. In addition to this, poor hygienic production conditions and absence of standard production method of tarhana may enhance of aflatoxin production by moulds.

In conclusion, aflatoxin producing mould species contaminate numerous food commodities, in warm climates where they may produce aflatoxins at different points of the food chain, such as preharvest, processing, transportation, or storage. The results of this study demonstrated that in spite of the low moisture and $\mathrm{pH}$ levels, moulds may grow and synthesized aflatoxins in tarhana. In order to prevent the health risk, a number of methods (storing in proper moisture and temperature, standardization of production method, improving the production conditions, microwave treatments, packing, etc.) can be applied to reduce/eliminate moulds from tarhana.

\section{References}

[1] N. Bilgiçli and S. Ibanoğlu, "Effect of wheat germ and wheat bran on the fermentation activity, phytic acid content and colour of tarhana, a wheat flour-yoghurt mixture," Journal of Food Engineering, vol. 78, no. 2, pp. 681-686, 2007.

[2] H. Erkan, S. Çelik, B. Bilgi, and H. Köksel, "A new approach for the utilization of barley in food products: barley tarhana," Food Chemistry, vol. 97, no. 1, pp. 12-18, 2006.

[3] S. Ibanoglu and E. Ibanoglu, "Rheological properties of cooked tarhana, a cereal-based soup," Food Research International, vol. 32, no. 1, pp. 29-33, 1999.

[4] M. Erbaş, M. Certel, and M. Kemal Uslu, "Microbiological and chemical properties of Tarhana during fermentation and storage as wet - Sensorial properties of Tarhana soup," LWT, vol. 38, no. 4, pp. 409-416, 2005.

[5] L. Settanni, H. Tanguler, G. Moschetti, S. Reale, V. Gargano, and H. Erten, "Evolution of fermenting microbiota in tarhana produced under controlled technological conditions," Food Microbiology, vol. 28, no. 7, pp. 1367-1373, 2011.

[6] N. Bilgiçli, "Effect of buckwheat flour on chemical and functional properties of tarhana," LWT, vol. 42, no. 2, pp. 514$518,2009$.

[7] S. Ibanoğlu and M. Maskan, "Effect of cooking on the drying behaviour of tarhana dough, a wheat flour-yoghurt mixture," Journal of Food Engineering, vol. 54, no. 2, pp. 119-123, 2002.

[8] M. Erbaş, M. Kemal Uslu, M. Ozgun Erbaş, and M. Certel, "Effects of fermentation and storage on the organic and fatty acid contents of tarhana, a Turkish fermented cereal food," Journal of Food Composition and Analysis, vol. 19, no. 4, pp. 294-301, 2006.

[9] N. Bilgiçli, A. Elgün, E. N. Herken, SelmanTürker, N. Ertaş, and S. Ibanoğlu, "Effect of wheat germ/bran addition on the chemical, nutritional and sensory quality of tarhana, a fermented wheat flour-yoghurt product," Journal of Food Engineering, vol. 77, no. 3, pp. 680-686, 2006.

[10] S. Ibanoğlu and P. Ainsworth, "Effect of canning on the starch gelatinization and protein in vitro digestibility of tarhana, a wheat flour-based mixture," Journal of Food Engineering, vol. 64, no. 2, pp. 243-247, 2004.

[11] O. Bozkurt and O. Gürbüz, "Comparison of lactic acid contents between dried and frozen tarhana," Food Chemistry, vol. 108, no. 1, pp. 198-204, 2008.

[12] I. Y. Sengun, D. S. Nielsen, M. Karapinar, and M. Jakobsen, "Identification of lactic acid bacteria isolated from Tarhana, a traditional Turkish fermented food," International Journal of Food Microbiology, vol. 135, no. 2, pp. 105-111, 2009.

[13] A. Zinedine, C. Brera, S. Elakhdari et al., "Natural occurrence of mycotoxins in cereals and spices commercialized in Morocco," Food Control, vol. 17, no. 11, pp. 868-874, 2006.

[14] H. Akiyama, Y. Goda, T. Tanaka, and M. Toyoda, "Determination of aflatoxins B1, B2, G1 and G2 in spices using a multifunctional column clean-up," Journal of Chromatography A, vol. 932, no. 1-2, pp. 153-157, 2001.

[15] A. Tarín, M. G. Rosell, and X. Guardino, "Use of highperformance liquid chromatography to assess airborne mycotoxins: aflatoxins and ochratoxin A," Journal of Chromatography A, vol. 1047, no. 2, pp. 235-240, 2004.

[16] A. Kamkar, "A study on the occurrence of aflatoxin M1 in Iranian Feta cheese," Food Control, vol. 17, no. 10, pp. 768775, 2006.

[17] M. Sharma and C. Márquez, "Determination of aflatoxins in domestic pet foods (dog and cat) using immunoaffinity 
column and HPLC," Animal Feed Science and Technology, vol. 93, no. 1-2, pp. 109-114, 2001.

[18] IARC Working Group on the Evaluation of Carcinogenic Risks to Humans, "Monographs on the evaluation of carcinogenic risk to humans: some naturally occuring substances," in Food Items and Constituents Heterocyclic Aromatic Amines and Mycotoxins, vol. 56, pp. 245-395, IARC, Şyon, France, 1993.

[19] E. Chiavaro, C. Dall'Asta, G. Galaverna et al., "New reversedphase liquid chromatographic method to detect aflatoxins in food and feed with cyclodextrins as fluorescence enhancers added to the eluent," Journal of Chromatography A, vol. 937, no. 1-2, pp. 31-40, 2001.

[20] G. Piva, F. Galvano, A. Pietri, and A. Piva, "Detoxification methods of aflatoxins. A review," Nutrition Research, vol. 15, no. 5, pp. 767-776, 1995.

[21] "Turkish Food Codex. Legislation about Determination of Maximum Levels of Certain Contaminants in Foods," Basbakanlik Basimevi. Ankara, Turkey, 2008.

[22] "Immunoaffinity column for sample clean up prior to analysis of aflatoxins," R5001/R5002. R-Biopharm GmbH, Darmstadt, Germany, 2005.

[23] "Enzyme immunoassay for the quantitative analysis of aflatoxins," article R4701, R-Biopharm GmbH, Darmstadt, Germany, 2002.

[24] "Enzyme immunoassay for the quantitative analysis of aflatoxin $\mathrm{B}_{1}$," R1211. R-Biopharm GmbH, Darmstadt, Germany, 2004.

[25] AOAC, Official Methods of Analysis, Association of Official Analytical Chemists, Washington, DC, USA, 15th edition, 1990.

[26] AOAC, Official Methods of Analysis, (Centennial Edition), Association of Official Analytical Chemists, Washington, DC, USA, 1984.

[27] W. F. Harrigan, Laboratory Methods in Food Microbiology, Academic Press, London, UK, 1998.

[28] M. Arici, "Microbiological studies and mycotoxin analysis of a fermented cereal product (Tarhana)," Ernahrungs-Umschau, vol. 47, p. 477, 2000.

[29] H. Soyyigit, "Isparta ve yöresinde üretilen ev yapımı tarhanaların mikrobiyolojik ve teknolojik özellikleri," Süleyman Demirel Üniversitesi Fen Bilimleri Enstitüsü Yüksek Lisans Tezi, Isparta, 2004.

[30] F. Coskun, “Trakya’nın değişik yörelerinde üretilen ev tarhanalarının kimyasal, mikrobiyolojik ve duyusal özellikleri üzerine bir araştırma," Gıda Mühendisliği Dergisi, vol. 12, pp. 48-52, 2002.

[31] O. Daglioglu, M. Arıcı, M. Konyalı, and T. Gumus, "Effects of tarhana fermentation and drying methods on the fate of Escherichia coli 0157:H7 and Staphylococcus aureus," European Food Research and Technology, vol. 215, no. 6, pp. 515-519, 2002.

[32] L. K. Berghofer, A. D. Hocking, D. Miskelly, and E. Jansson, "Microbiology of wheat and flour milling in Australia," International Journal of Food Microbiology, vol. 85, no. 1-2, pp. 137-149, 2003.

[33] N. Karagozlu and M. Karapinar, "Bazı tahıl ve ürünlerinde okratoksin-a ve fungal kontaminasyon," Turkish Journal of Biology, vol. 24, pp. 561-572, 2000.

[34] B. Giray, G. Girgin, A. B. Engin, S. Aydin, and G. Sahin, "Aflatoxin levels in wheat samples consumed in some regions of Turkey," Food Control, vol. 18, no. 1, pp. 23-29, 2007.

[35] H. Colak, E. B. Bingol, H. Hampikyan, and B. Nazli, "Determination of aflatoxin contamination in red-scaled, red and black pepper by ELISA and HPLC," Journal of Food and Drug Analysis, vol. 14, no. 3, pp. 292-296, 2006.

[36] N. Karagozlu, B. Ergonul, and C. Karagozlu, "Microbiological attributes of instant tarhana during fermentation and drying," Bulgarian Journal of Agricultural Science, vol. 14, no. 6, pp. 535-541, 2008.

[37] O. Sagdıc, H. Soyyigit, S. Ozcelik, and H. Gul, "Viability of Escherichia coli O157:H7 during the fermentation of tarhana produced with different spices," Annals of Microbiology, vol. 55, no. 2, pp. 97-100, 2005. 

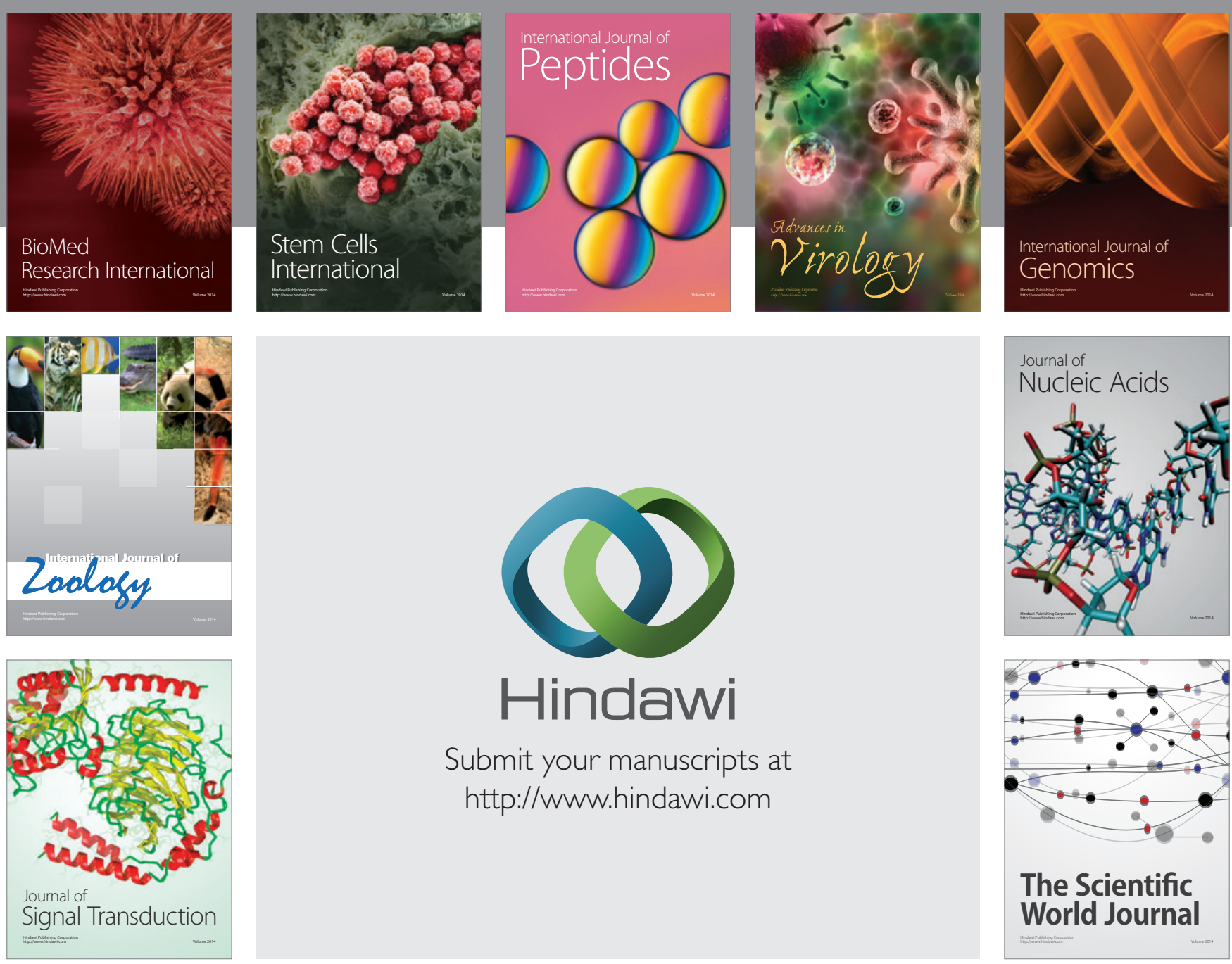

Submit your manuscripts at

http://www.hindawi.com
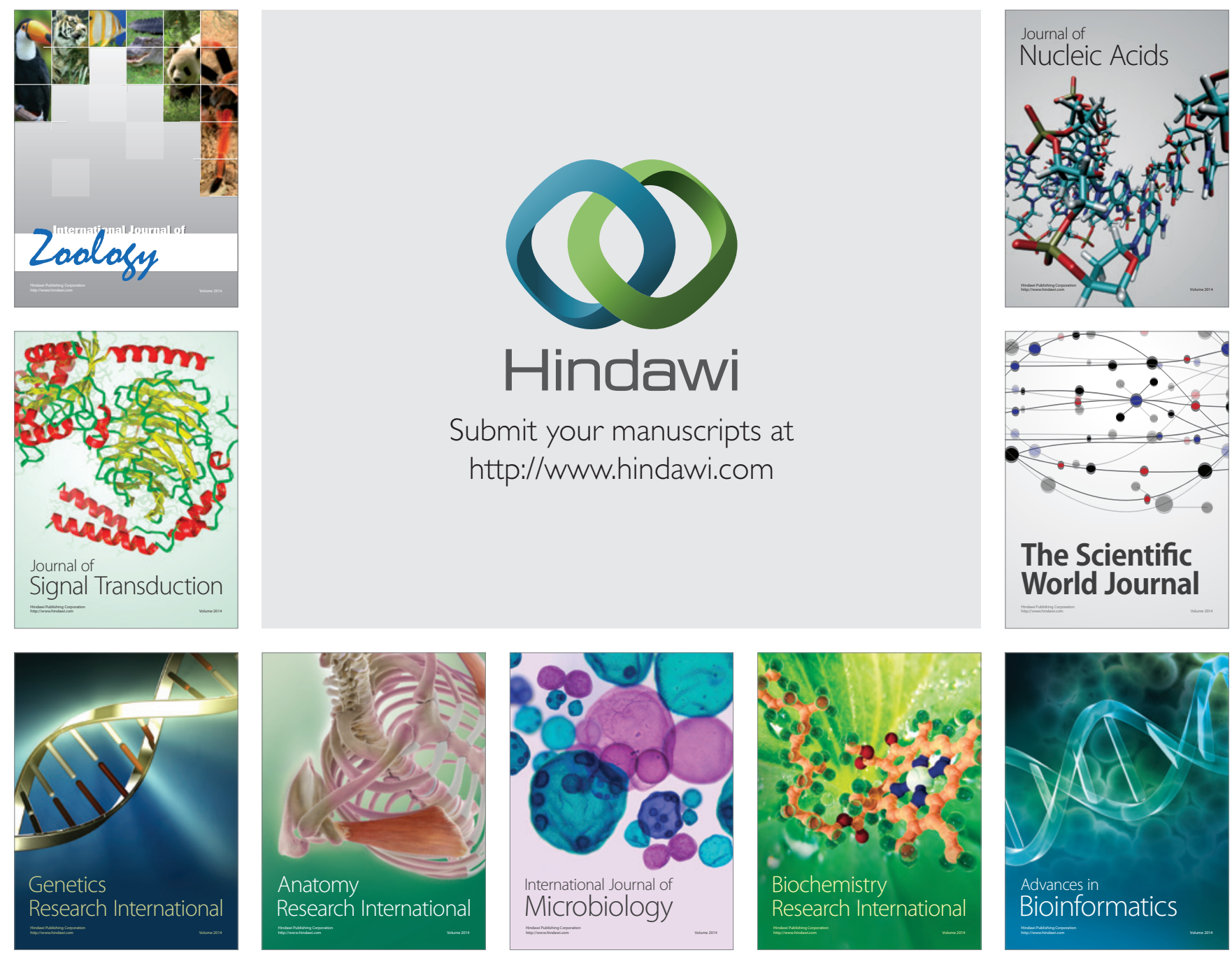

The Scientific World Journal
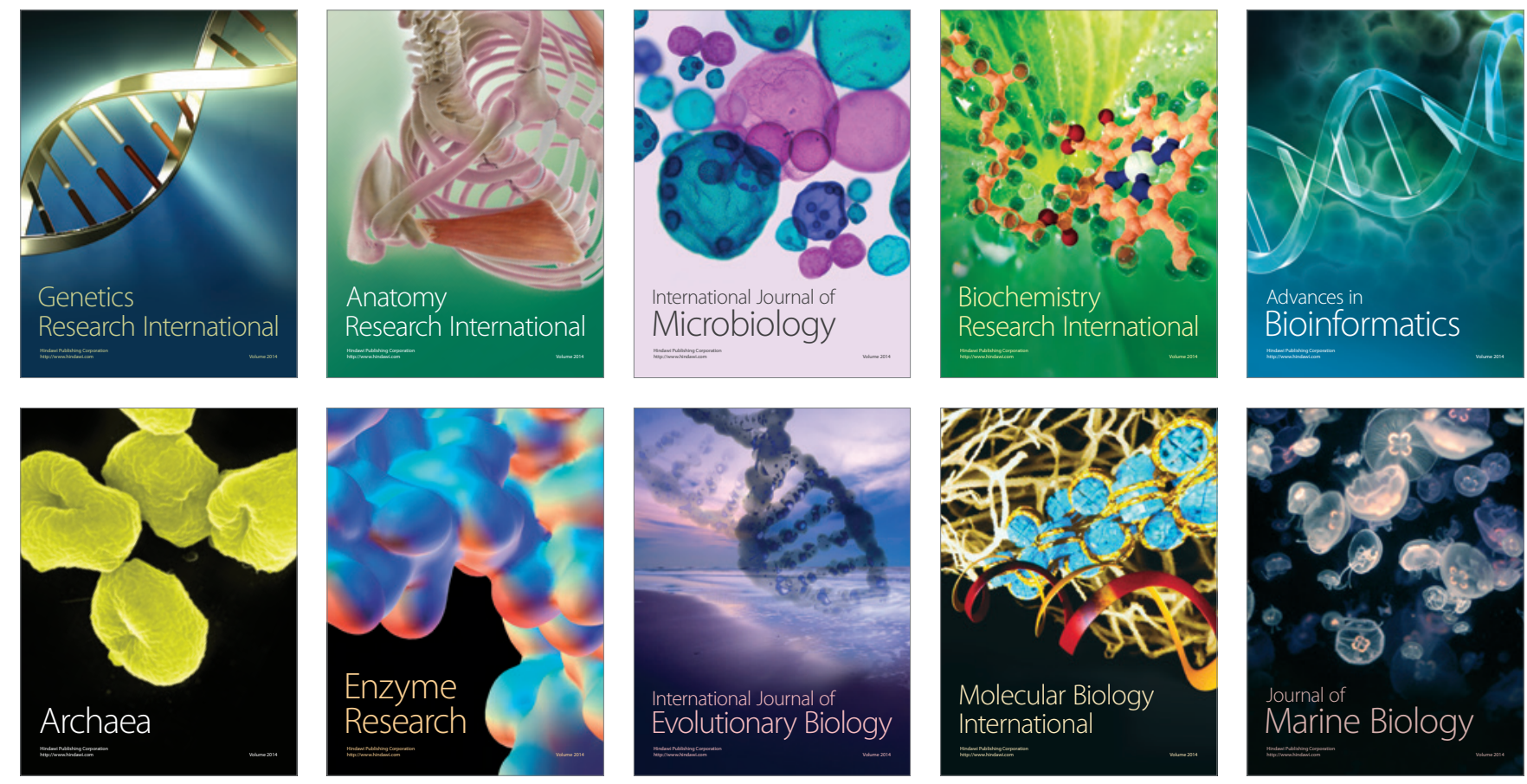